\title{
Article \\ A Viral Long Non-Coding RNA Protects against Cell Death during Human Cytomegalovirus Infection of CD14+ Monocytes
}

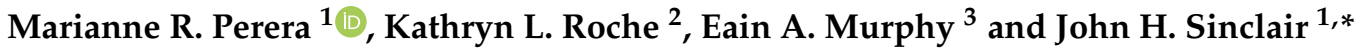 \\ 1 Cambridge Institute of Therapeutic Immunology and Infectious Disease, Department of Medicine, University \\ of Cambridge, Addenbrooke's Hospital, Hills Road, Cambridge CB2 0QQ, UK; mp704@cam.ac.uk \\ 2 Evrys Bio, Pennsylvania Biotechnology Center, Doylestown, PA 18902, USA; kate@evrysbio.com \\ 3 Microbiology and Immunology Department, SUNY Upstate Medical University, Syracuse, NY 13210, USA; \\ murphye1@upstate.edu \\ * Correspondence: js152@cam.ac.uk
}

check for updates

Citation: Perera, M.R.; Roche, K.L.; Murphy, E.A.; Sinclair, J.H. A Viral Long Non-Coding RNA Protects against Cell Death during Human Cytomegalovirus Infection of CD14+ Monocytes. Viruses 2022, 14, 246. https://doi.org/10.3390/v14020246 Academic Editor: Clinton Jones

Received: 14 January 2022 Accepted: 21 January 2022 Published: 26 January 2022

Publisher's Note: MDPI stays neutral with regard to jurisdictional claims in published maps and institutional affiliations.

Copyright: (C) 2022 by the authors. Licensee MDPI, Basel, Switzerland. This article is an open access article distributed under the terms and conditions of the Creative Commons Attribution (CC BY) license (https:// creativecommons.org/licenses/by/ $4.0 /)$.

\begin{abstract}
Long non-coding RNA $\beta 2.7$ is the most highly transcribed viral gene during latent human cytomegalovirus (HCMV) infection. However, as yet, no function has ever been ascribed to $\beta 2.7$ during HCMV latency. Here we show that $\beta 2.7$ protects against apoptosis induced by high levels of reactive oxygen species (ROS) in infected monocytes, which routinely support latent HCMV infection. Monocytes infected with a wild-type (WT) virus, but not virus deleted for the $\beta 2.7$ gene $(\Delta \beta 2.7)$, are protected against mitochondrial stress and subsequent apoptosis. Protected monocytes display lower levels of ROS and additionally, stress-induced death in the absence of $\beta 2.7$ can be reversed by an antioxidant which reduces ROS levels. Furthermore, we show that infection with WT but not $\Delta \beta 2.7$ virus results in strong upregulation of a cellular antioxidant enzyme, superoxide dismutase 2 (SOD2) in CD14+ monocytes. These observations identify a role for the $\beta 2.7$ viral transcript, the most abundantly expressed viral RNA during latency but for which no latency-associated function has ever been ascribed, and demonstrate a novel way in which HCMV protects infected monocytes from pro-death signals to optimise latent carriage.
\end{abstract}

Keywords: human cytomegalovirus; latency; long non-coding RNA; reactive oxygen species; apoptosis; oxidative stress

\section{Introduction}

Human cytomegalovirus (HCMV) is a widespread beta-herpesvirus that infects $40-100 \%$ of populations worldwide [1]. After primary infection, the virus can establish a latent lifecycle in cells of the early myeloid lineage, where it persists for the lifetime of the host. A hallmark of latent infection is the carriage of viral genomes in the absence of the production of infectious virions in a form that is able to reactivate and resume a full lytic infection. One important site of HCMV latency is in undifferentiated myeloid cells, such as CD34+ progenitor cells and their derivative CD14+ monocytes [2-6]. During latent carriage, latency-associated gene expression is known to have profound effects on the latent cell and its environment to ensure virus survival and dissemination (reviewed in [7]).

It is becoming increasingly clear that latency-associated gene expression is more complex than first thought [8-10]. Transcriptome analyses of monocytes and CD34+ve progenitor cells have demonstrated that the most highly transcribed viral gene during HCMV latency is the $\beta 2.7$ long non-coding RNA (also known as RNA2.7) [10,11]. Long non-coding RNAs (lncRNAs) are defined as RNAs over 200 nucleotides in length with little or no protein-coding potential, but with diverse roles, which can range from acting as scaffolds for the assembly of protein complexes, to functional 'microRNA sponges' where they bind and sequester miRNAs away from their targets (reviewed in [12]). However, the function/s of $\beta 2.7$ during latency remains unclear. 
During a lytic infection, where $\beta 2.7$ is also the most highly transcribed viral gene, accounting for approximately $46.8 \%$ of polyadenylated viral RNA at $72 \mathrm{~h}$ post infection (h.p.i) [13], it is known to protect lytically infected cells from apoptosis induced by rotenone by its interaction with mitochondrial Complex I, but the mechanism of how this protection occurs has not yet been identified [14].

Consequently, we have analysed the role of $\beta 2.7$ expression in monocytes, in which HCMV is known to undergo a latent infection. We find that $\beta 2.7$ does indeed protect infected monocytes from apoptosis and that this is mediated by preventing the accumulation of high levels of ROS, likely at least in part via upregulation of superoxide dismutase 2 (SOD2).

\section{Materials and Methods}

\subsection{Cells}

Primary CD14+ monocytes were isolated from the peripheral blood of healthy donors or from apheresis cones (NHS Blood \& Transport Service, Cambridge, UK) as described in Poole et al. [15]. In brief, peripheral blood mononuclear cells (PBMC) were separated from whole blood by density-gradient centrifugation using Lymphoprep ${ }^{\mathrm{TM}}$ (Stem Cell Technologies, Vancouver, Canada), and monocytes were isolated from PBMC by magneticactivated cell sorting (MACS) with CD14+ microbeads (Miltenyi Biotech, Bergisch Gladbach, Germany). Monocytes were cultured in X-Vivo15 media (Lonza, Basel, Switzerland) at $37{ }^{\circ} \mathrm{C}$ in a $5 \% \mathrm{CO}_{2}$ atmosphere. Where stated, monocytes were treated with $50 \mu \mathrm{M}$ cadmium chloride (Sigma, St Louis, MO, USA), N-acetyl cysteine (A9165, Sigma) or MitoTEMPO (Item no. 16,621, Cayman Chemical, Ann Arbor, MI, USA).

\subsection{Human Cytomegaloviruses}

WT Toledo and $\Delta \beta 2.7$ Toledo viruses were kind gifts from Gavin Wilkinson and are described in McSharry et al. [16]. WT TB40/E-SV40-GFP, also known as TB40/E-eGFP, is described in [17], and was used to generate $\Delta \beta 2.7 \mathrm{~TB} 40 / \mathrm{E}$ by standard BAC recombineering protocols detailed in [18-20], using the primers listed in Table 1.

Table 1. Primer sequences used to generate $\Delta \beta 2.7$ TB40/E. Underlined sequence denotes sequence shared with galK.

\begin{tabular}{cc}
\hline Primer & Sequence \\
\hline galK insertion $\mathrm{F}$ & CATCCCAAGCACTCCACACGCTATCACAGACCACGGACACGGCAAAAAAT \\
CCTGTTGACAATTAATCATCGGCA
\end{tabular}

In brief, the sequence from nt 35,220 up to the TATA box at nt 37,726 within the TB40/E BAC4 sequence listed in EF999921 was deleted by homologous recombination with the galK gene. The galK gene was subsequently removed from the $\mathrm{BAC}$, again by homologous recombination, using the reversion primers listed in Table 1. All recombinant viruses were validated for deletion of $\beta 2.7$ by genome PCR analysis and sequencing across the deletion site.

Viruses were propagated by inoculating HFFs at an MOI of 0.1 . At $90 \%$ infection, the supernatant was harvested every 2-3 days and centrifuged for $10 \mathrm{~min}$ at $1500 \times \mathrm{g}$, before being frozen at $-80^{\circ} \mathrm{C}$. To concentrate virus, supernatants were defrosted and spun for $2 \mathrm{~h}$ at $18^{\circ} \mathrm{C}$ at $14,500 \times g$ in an Avanti-J25 centrifuge with a JLA-16.250 rotor (Beckman Coulter). The pellet was resuspended in X-Vivo 15 media, aliquoted, and then stored at $-80^{\circ} \mathrm{C}$. Prior 
to use, concentrated virus was defrosted and spun for $2 \mathrm{~min}$ at $800 \times g$ to further remove any cellular debris.

Monocytes were inoculated with virus at a multiplicity of infection (MOI) of 3 as based on titration on RPE-1 cells, and incubated for $3 \mathrm{~h}$, before being washed twice with PBS and given fresh X-Vivo15 media.

Ultra-violet light (UV) inactivation of virus was conducted by placing samples in a tissue culture plate within $10 \mathrm{~cm}$ of a UV germicidal $(254 \mathrm{~nm})$ lamp for $30 \mathrm{mins}$ as described in [21].

\subsection{Fluorescence Microscopy}

Mitochondrial membrane potential was assayed using tetramethylrhodamine, ethyl ester (TMRE, Abcam). Cells were stained with 50 nM TMRE (Abcam, ab113852) and Hoechst 33,342 stain (Sigma, B2261) for $30 \mathrm{~min}$ at $37^{\circ} \mathrm{C}$ in the dark, prior to being washed once with PBS and imaged on a widefield Nikon TE200 microscope. Percentage of TMREstained cells was determined from 3 fields of view per replicate over at least 3 independent biological repeats.

Superoxide was stained with MitoSOX ${ }^{\mathrm{TM}}$ Red (ThermoFisher, Waltham, MA, USA). MitoSOX reagent was added to cells to a final concentration of $1 \mu \mathrm{M}$ for $10 \mathrm{~min}$ at $37{ }^{\circ} \mathrm{C}$ in the dark. Cells were then washed three times with warm Hank's buffered saline solution (HBSS, Sigma), Hoeschst stained and imaged on a widefield Nikon TE200 microscope. Quantification of MitoSOX fluorescence was performed using ImageJ software, analysing a minimum of 400 cells per replicate.

\subsection{Sodium Dodecyl Sulphate-Polyacrylamide Gel Electrophoresis (SDS-PAGE) and Western Blotting}

Samples were directly lysed in Laemmli Buffer and separated by SDS-PAGE on a $12 \%$ polyacrylamide gel. Separated proteins were transferred to Hybond nitrocellulose membranes (Amersham Biosciences, Amersham, UK) and blocked in 5\% milk in Trisbuffered saline (milk-TBS). Primary antibodies were diluted in milk-TBS as follows: cleaved caspase-3 (CST, \#9664, 1/500), PARP (CST, \#9542, 1/1000), ß-actin (Abcam, ab8227, 1/2000), SOD2 (Abcam, ab13533, 1/1000), and GPX-1 (Abcam, ab22604, 1/1000), and incubated with membranes overnight at $4{ }^{\circ} \mathrm{C}$. Secondary antibody (chicken anti-rabbit-HRP, Abcam, ab6829, 1/2000) was incubated with membrane for $1 \mathrm{hr}$ at room temperature. Blots were incubated with Amersham ECL Western Blotting detection reagent (GE Healthcare Life Sciences) for $5 \mathrm{~min}$ and then exposed to autoradiography film (Fujifilm, Tokyo, Japan). All densitometry analysis was performed using ImageJ software.

\section{Results}

\section{1. $\beta 2.7$ Protects against Mitochondrial Stress in Infected Monocytes}

To test if $\beta 2.7$ has a protective role during latent infection, we stressed infected monocytes with cadmium chloride $\left(\mathrm{CdCl}_{2}\right)$, which is an established way of causing apoptosis in primary lymphocytes and monocytes by inducing loss of mitochondrial membrane potential (MMP) [22,23]; similar effects have also been demonstrated in monocytic U937 and THP-1 cell lines [24,25]. The exact mechanism by which cadmium causes loss of MMP and cytotoxicity in monocytic cells is unclear: some reports suggest cadmium activates caspase-8 [24] while others suggest its similarity in diameter and charge to calcium allows it to competitively inhibit calcium influx [24]. However, multiple studies have indicated that cadmium increases ROS levels [22,25,26]. Consequently, we tested the effect of cadmium ions in infected monocytes in the presence or absence of $\beta 2.7$ gene expression.

We started by analysing mitochondrial function in infected monocytes using the fluorescent dye, TMRE, a positively charged, cell permeant molecule which accumulates in the mitochondrial matrix of actively respiring mitochondria. It therefore serves as a measure of MMP, such that mitochondrial oxidative phosphorylation uncouplers such as 
FCCP, which disrupts ATP synthesis by depolarising mitochondrial membrane potential, cause dye dispersal and loss of TMRE fluorescence (Figure 1A-C, and reviewed in [27]).

A)

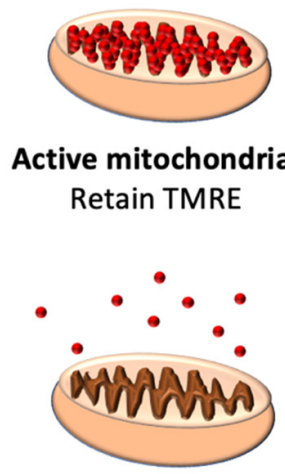

\section{Unhealthy mitochondria \\ TMRE does not accumulate in matrix}

B)

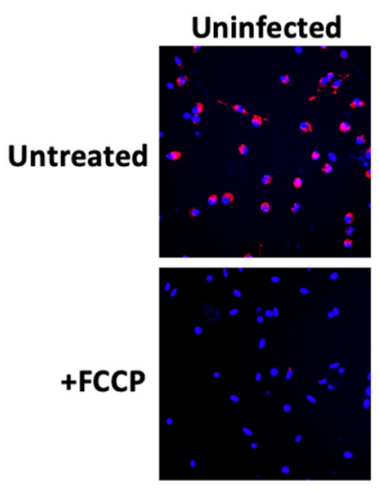

C)

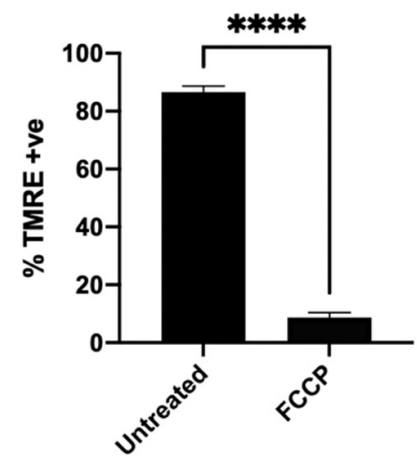

Figure 1. TMRE measures mitochondrial membrane potential (MMP) in monocytes. (A) TMRE, a fluorescent, positively charged stain, accumulates in actively respiring mitochondria because the mitochondrial matrix is negatively charged. When the mitochondrial membrane potential is dissipated, TMRE disperses. (B) Primary CD14+ monocytes isolated from peripheral blood were left untreated or treated with $20 \mu \mathrm{M}$ FCCP, an uncoupler, for $10 \mathrm{~min}$. Cells were then TMRE and Hoechst stained and photographed on a fluorescence microscope. Graph in (C) shows mean \% TMRE + ve cells from samples analysed in triplicate. Significance was determined by a two-tailed Student's $t$-test. $* * * *=p<0.0001$.

To investigate the protective function of $\beta 2.7$ during latent infection, we mock infected, or infected CD14+ monocytes with wild type (WT) virus or virus with a $\beta 2.7$ gene deletion $(\Delta \beta 2.7)$ in the Toledo strain of HCMV. Monocytes infected with HCMV are known to undergo latent infection which can be maintained in long-term culture $[5,11,28-32]$ and the Toledo strain of HCMV has been shown to undergo latent infection in myeloid progenitor cells [33-37]. Fourteen days post infection (d.p.i), cells were either treated or mock-treated with cadmium chloride for $24 \mathrm{~h}$, and then TMRE and Hoechst stained. As expected, the addition of cadmium chloride to mock infected cells caused a severe drop in the number of cells with visible TMRE staining, indicating mitochondrial depolarization (Figure 2A,B). By contrast, monocytes infected with WT virus were partially protected from this cadmium-induced loss of TMRE staining, but this protection was lost in the absence of $\beta 2.7$ (Figure 2A,B). This strongly suggests that $\beta 2.7$ has a protective role against mitochondrial stress in latent infection. 
A)
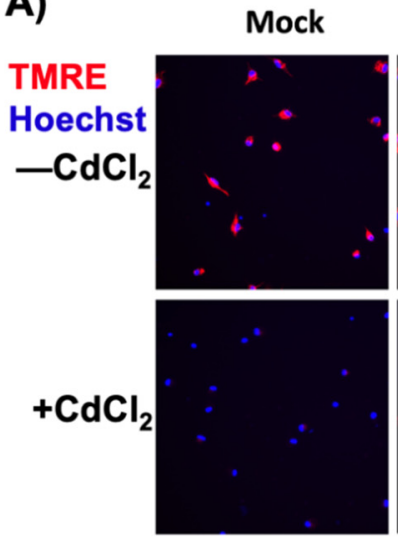

WT
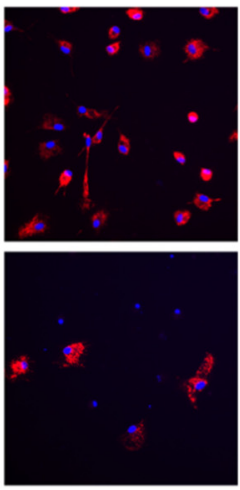

$\Delta \beta 2.7$
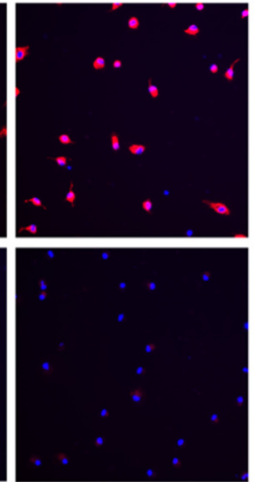

B)

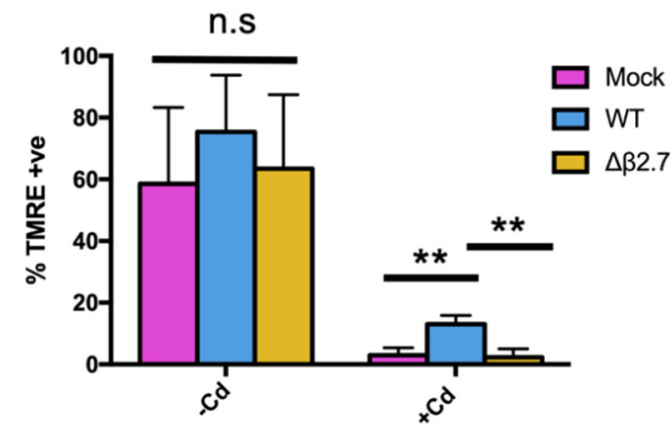

C)

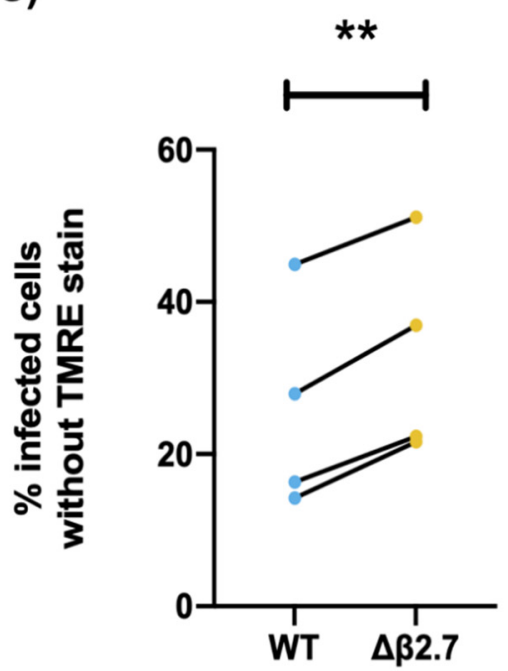

D)

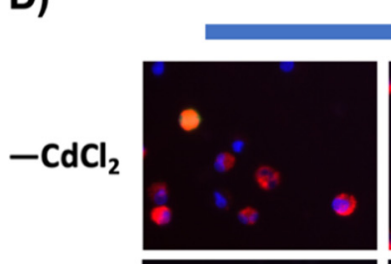

WT
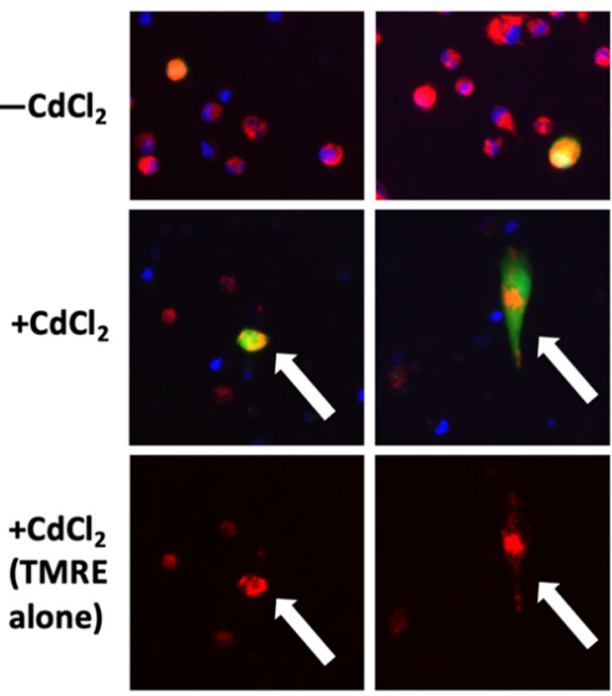

$\Delta \beta 2.7$
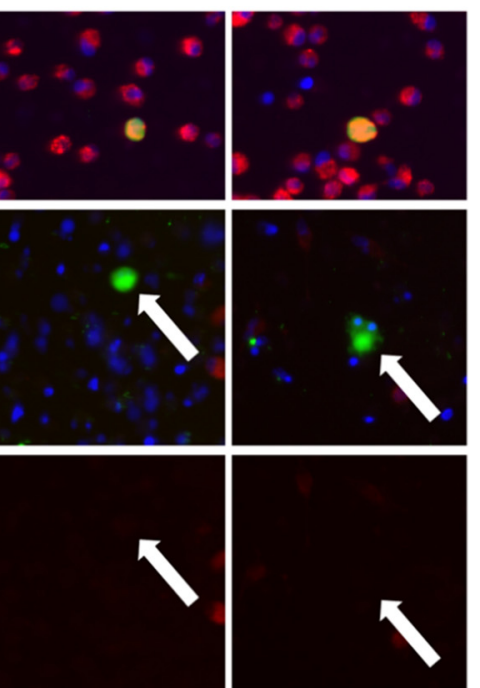

Figure 2. $\beta 2.7$ protects against cadmium chloride-induced mitochondrial stress in HCMV infected CD14+ monocytes. (A,B) CD14+ monocytes were mock infected or infected with a WT or $\Delta \beta 2.7$ HCMV Toledo virus. At 14 d.p.i, half the cells were treated with $50 \mu \mathrm{M}$ cadmium chloride for $24 \mathrm{~h}$. All cells were then TMRE and Hoechst stained and photographed on a fluorescence microscope in (A). Graph in (B) shows mean \% of TMRE + ve cells over three independent biological repeats. Error bars show standard deviation. Significant difference between mock and WT or WT and $\Delta \beta 2.7$ was determined using a one-way ANOVA with Tukey post hoc analysis. (C) CD14+ monocytes were infected with WT or $\Delta \beta 2.7$ HCMV TB40/E-SV40-GFP. 2 d.p.i, cells were treated with $50 \mu \mathrm{M}$ $\mathrm{CdCl}_{2}$ for $24 \mathrm{~h}$ and then TMRE and Hoechst stained. GFP + ve cells with and without visible TMRE staining were enumerated. Graph shows the mean from 4 independent biological repeats from different blood donors. Statistical significance was determined by two-tailed paired $t$-test. ${ }^{* *}=p<0.01$. (D) Representative photos of CD14+ monocytes infected with WT or $\Delta \beta 2.7$ TB40/E-SV40-GFP that were treated with $\mathrm{CdCl}_{2}$ for $24 \mathrm{~h}$ at 4 d.p.i, and then TMRE and Hoechst stained. n.s. = not significant.

To ensure this effect was not virus isolate-specific and to specifically analyse infected cells in the cell population (which could not be tracked in untagged WT Toledo virus infections), we repeated this analysis at earlier timepoints ( 3 d.p.i and 5 d.p.i) with GFPtagged WT or GFP-tagged $\Delta \beta 2.7$ TB40/E viruses (Figure 2C,D). WT infected monocytes consistently retained their TMRE staining when treated with cadmium chloride, but this protection was lost when cells were infected with $\Delta \beta 2.7$ virus, again indicating that $\beta 2.7$ protects cells from mitochondrial stress during latency. 


\section{2. $\beta 2.7$ Protects against Apoptosis in HCMV Infected Monocytes}

A loss in MMP is known to either stimulate apoptosis or be a consequence of it [38]. Therefore, we next tested whether the cadmium-induced loss of MMP in monocytes was accompanied by apoptosis and whether this was impacted upon by latent infection. Primary CD14+ monocytes were isolated and either mock infected or infected with WT or $\Delta \beta 2.7$ Toledo virus. At 6 d.p.i, cells were treated or mock treated with $\mathrm{CdCl}_{2}$ and $24 \mathrm{~h}$ post treatment, protein was harvested and assayed for levels of cleaved caspase-3, a hallmark of apoptosis (Figure 3). Addition of $\mathrm{CdCl}_{2}$ to mock infected cells resulted in detectable cleaved caspase- 3 levels which was not observed in WT virus-infected cells treated with cadmium (Figure 3). By contrast, cadmium-treated $\Delta \beta 2.7$-infected cells showed a dramatic increase in cleaved caspase-3. Taken together, these results suggest that cadmium treatment of monocytes results in low, but discernible induction of apoptotic markers, which is prevented by infection with WT virus. In contrast, this protection is lost in the absence of $\beta 2.7$ and, indeed, infection with $\Delta \beta 2.7$ virus results in a massively increased level of cleaved caspase-3, suggesting that infection itself substantially stresses the cells but the presence of $\beta 2.7$ reverses this phenotype. Therefore, viral $\beta 2.7$ appears to be important in protecting infected monocytes from stress-induced apoptosis.

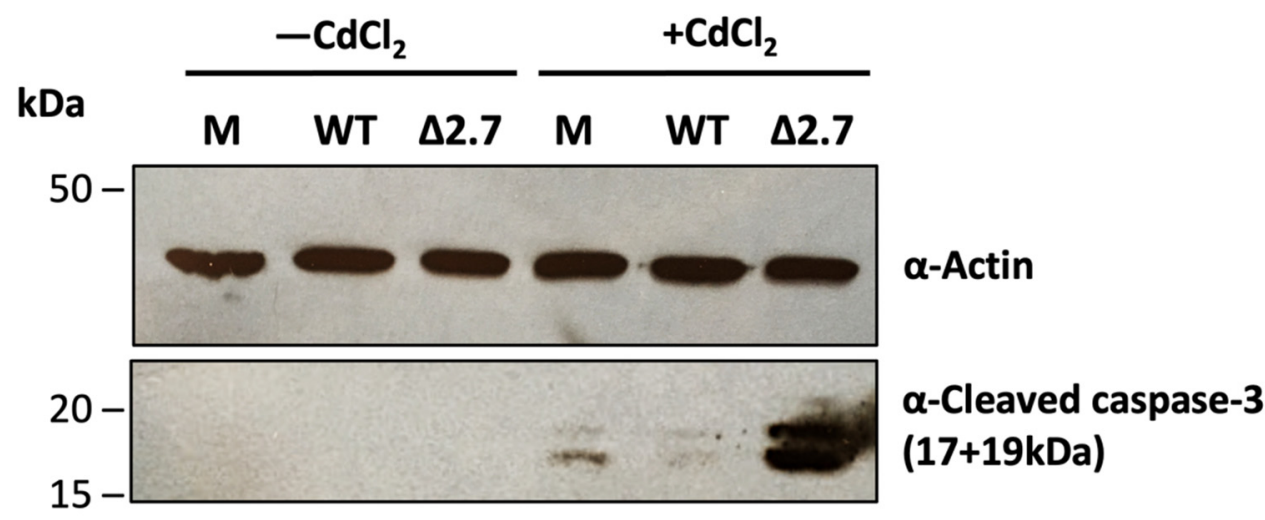

Figure 3. $\beta 2.7$ protects against cadmium-induced apoptosis in infected monocytes. CD14+ monocytes were mock, WT or $\Delta \beta 2.7 \mathrm{HCMV}$ Toledo infected and at 6 d.p.i were treated with $50 \mu \mathrm{M} \mathrm{CdCl}_{2}$ for $24 \mathrm{~h}$. Protein lysates from these cells were assessed for levels of cleaved caspase- 3 and the loading control actin by immunoblot.

\section{3. $\beta 2.7$ Lowers ROS Levels in Infected Monocytes}

HCMV infection protects monocytes from cadmium-induced cell death (Figures 2 and 3). As cadmium is an inducer of ROS in monocytic cells [22,25], and the $\beta 2.7$ gene in the absence of other HCMV factors, lowers ROS levels when over-expressed in rat aortic endothelial cells [39], we reasoned that $\beta 2.7$ might lower ROS levels in the context of a latent infection. ROS are formed when oxygen accepts an extra electron to produce a highly reactive molecule. This includes free radicals such as superoxide $\left(\mathrm{O}_{2}{ }^{*}\right)$ and hydroxyl radicals $\left(\mathrm{HO}^{*}\right.$-), as well as their derivatives, e.g., hydrogen peroxide $\left(\mathrm{H}_{2} \mathrm{O}_{2}\right)$, peroxynitrite (ONOO-), and hypochlorous acid (HOCl) [40]. At high levels (known as oxidative stress), they react with and damage, proteins, DNA, and lipids, ultimately leading to apoptosis and/or necrosis [41,42]. The majority of ROS production in the cell can be traced to complex I and complex III of the electron transport chain in the mitochondria; though in phagocytic cells, they are also generated in the extracellular fluid or interior of phagosomes by NADPH oxidase (NOX) [43].

To test whether $\beta 2.7$ modulates ROS levels during a latent infection, we mock infected or infected CD14+ monocytes with WT or $\Delta \beta 2.7$ Toledo virus for 6 days and then treated them with cadmium chloride. Twenty-four hours post treatment, cells were stained with Hoechst and MitoSOX, a mitochondrial superoxide dye (Figure 4). 
A)

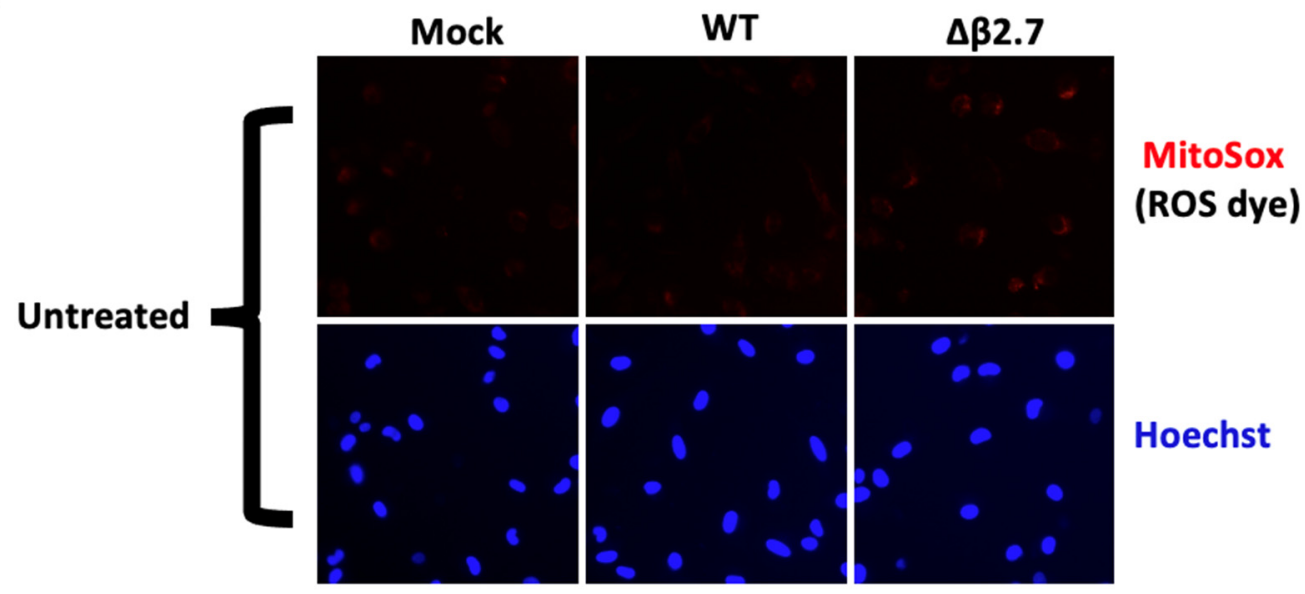

B)

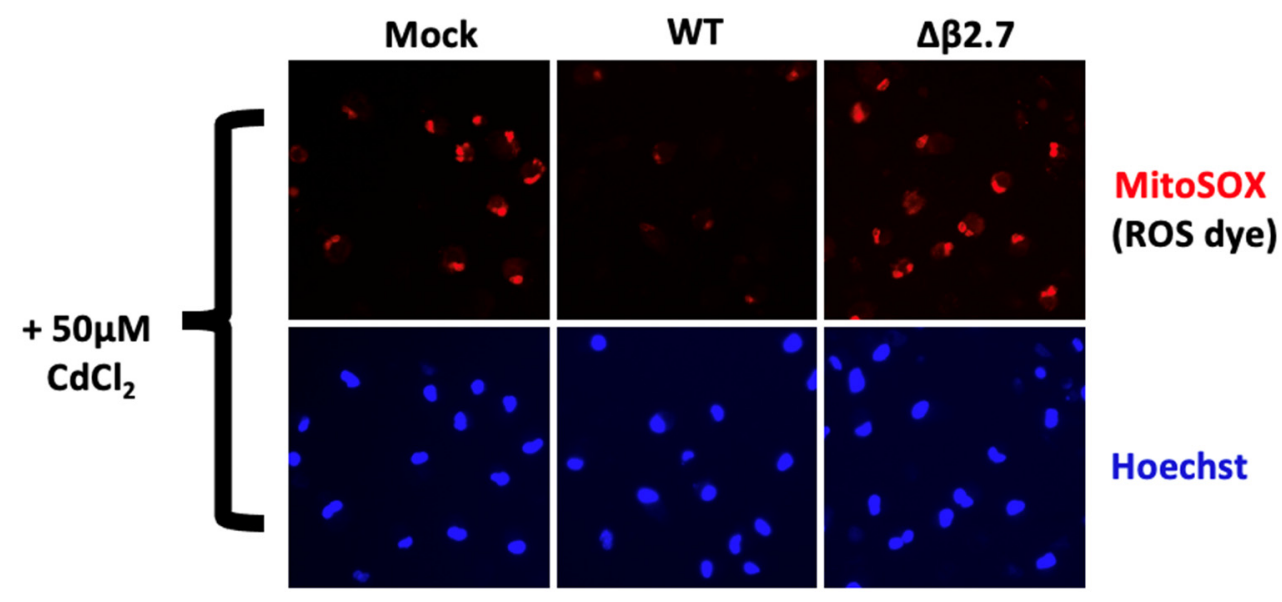

C)

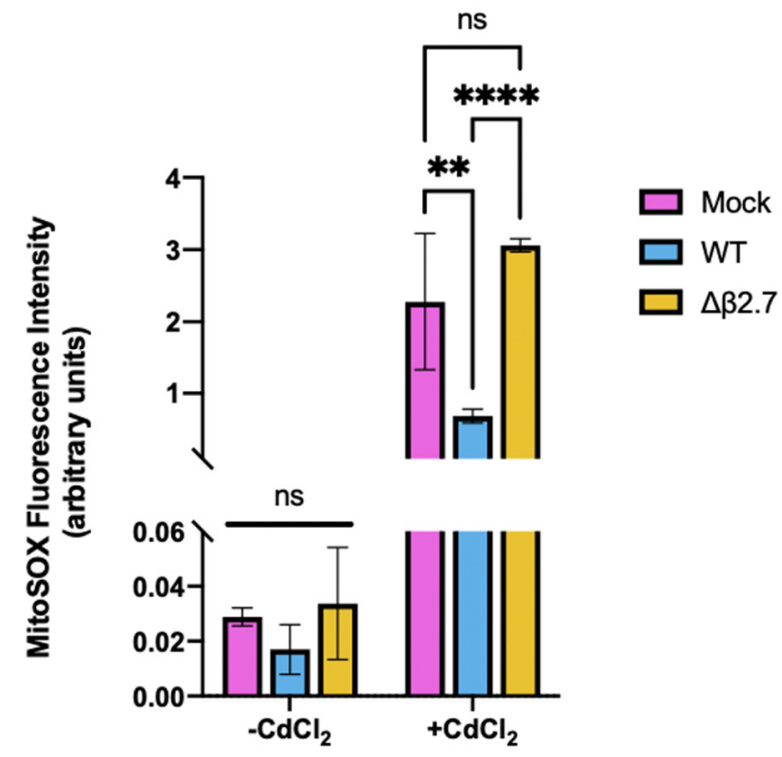

Figure 4. $\beta 2.7$ protects against high ROS levels in infected monocytes. Primary CD14+ monocytes were isolated from peripheral blood and either mock infected or infected with WT or $\triangle \beta 2.7 \mathrm{HCMV}$ Toledo. 6 d.p.i, cells were untreated (A) or treated with $50 \mu \mathrm{M} \mathrm{CdCl}_{2}$ (B) for $24 \mathrm{~h}$. Cells were then stained with Hoechst and the superoxide dye, MitoSOX, and imaged by fluorescence microscopy. (C) Quantification of MitoSOX fluorescence/cell for experiments described in A and B, where graph shows mean and standard deviation for three replicate experiments. Significance was determined by a two-way ANOVA with Tukey post hoc testing. ns $=$ not significant, ${ }^{* *}=p<0.01$, and ${ }^{* * *}=p<0.0001$. 
Consistent with $\beta 2.7$ protecting cells from superoxide induction during infection, we observed increased MitoSOX staining in $\Delta \beta 2.7$ infected cells even in the absence of exogenous ROS induction, indicating that infection in the absence of $\beta 2.7$ increases ROS levels (Figure $4 \mathrm{~A}$ ). This difference became substantially more pronounced when cells were also stressed with cadmium chloride: exogenously stressed cells infected with $\Delta \beta 2.7$ Toledo virus displayed much higher levels of superoxide than WT infected cells (Figure 4B,C). Interestingly, protection from high ROS levels seemed to occur in all cells observed rather than a subset of infected cells. Protection of bystander cells could be mediated by a secreted factor, which we further address in Section 3.5.

\subsection{Antioxidants or $\beta 2.7$ Reduce ROS Levels Induced by Cadmium to Prevent Apoptosis}

Although our observations clearly showed that $\beta 2.7$ expression results in lower ROS levels, as well as protection from apoptosis in exogenously stressed cells, it was important to determine whether the high ROS levels we observed in the absence of $\beta 2.7$ were driving cell death rather than simply being a side effect of it. To address this, we first tested whether ROS were causing mitochondrial stress by adding cadmium to CD14+ monocytes following treatment with increasing concentrations of antioxidants to lower ROS. We then measured MMP to test whether lowering ROS levels with an antioxidant would rescue mitochondrial activity. As can be seen in Figure 5A,B, the use of two different antioxidants, either $\mathrm{N}$-acetyl cysteine (NAC) or MitoTEMPO, prevented the loss of MMP induced by cadmium ions in CD14+ monocytes. This suggests that high ROS levels induced by cadmium are indeed responsible for the loss in MMP and are not simply a by-product of cell stress.

We then wished to investigate whether the antioxidant, NAC, would also rescue $\Delta \beta 2.7$ infected cells from cadmium-induced apoptosis. We treated mock, WT or $\Delta \beta 2.7$ virus-infected monocytes with cadmium, with or without NAC, and immunoblotted protein lysates from these cells for cleaved caspase- 3 and cleaved PARP (both indicative of apoptosis). As expected, treatment of monocytes with cadmium induced detectable levels of cleaved caspase-3 and cleaved PARP which was substantially increased in $\Delta \beta 2.7$ infected cells (Figure 5C). However, the addition of NAC to $\triangle \beta 2.7$-infected monocytes prevented this increase in cleaved caspase- 3 or cleaved PARP, consistent with high ROS levels being a major factor in inducing apoptosis in $\Delta \beta 2.7$ infected cells. 
A)

TMRE and Hoechst stained CD14+ monocytes

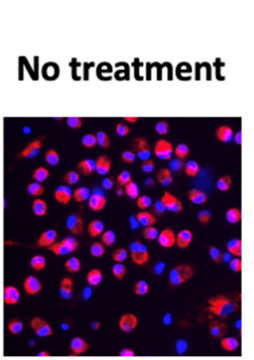

$+50 \mu \mathrm{M} \mathrm{CdCl}_{2}$

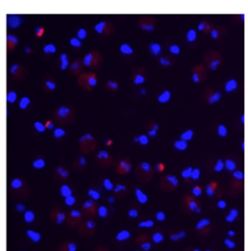

OmM

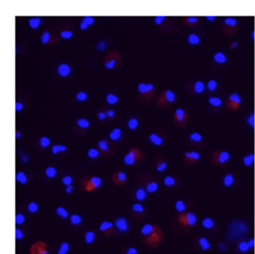

$0.05 \mathrm{mM}$

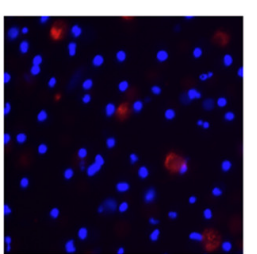

$0.1 \mathrm{mM}$

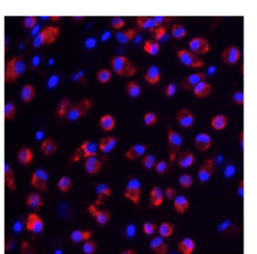

$0.5 \mathrm{mM}$

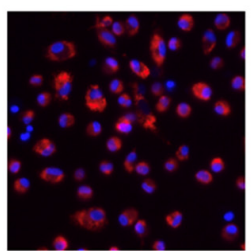

$1 \mathrm{mM}$

B)

\section{NAC concentration}

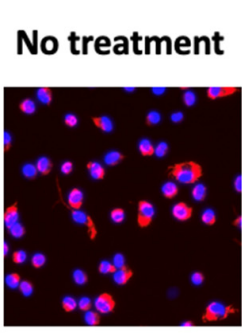

$+50 \mu \mathrm{M} \mathrm{CdCl}{ }_{2}$
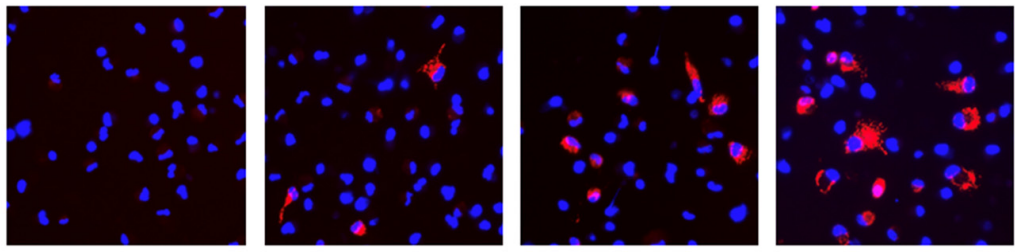

$0 \mu \mathrm{M}$

$1 \mu \mathrm{M}$

$5 \mu \mathrm{M}$

$10 \mu \mathrm{M}$

MitoTEMPO concentration

C) $\mathrm{kDa}$

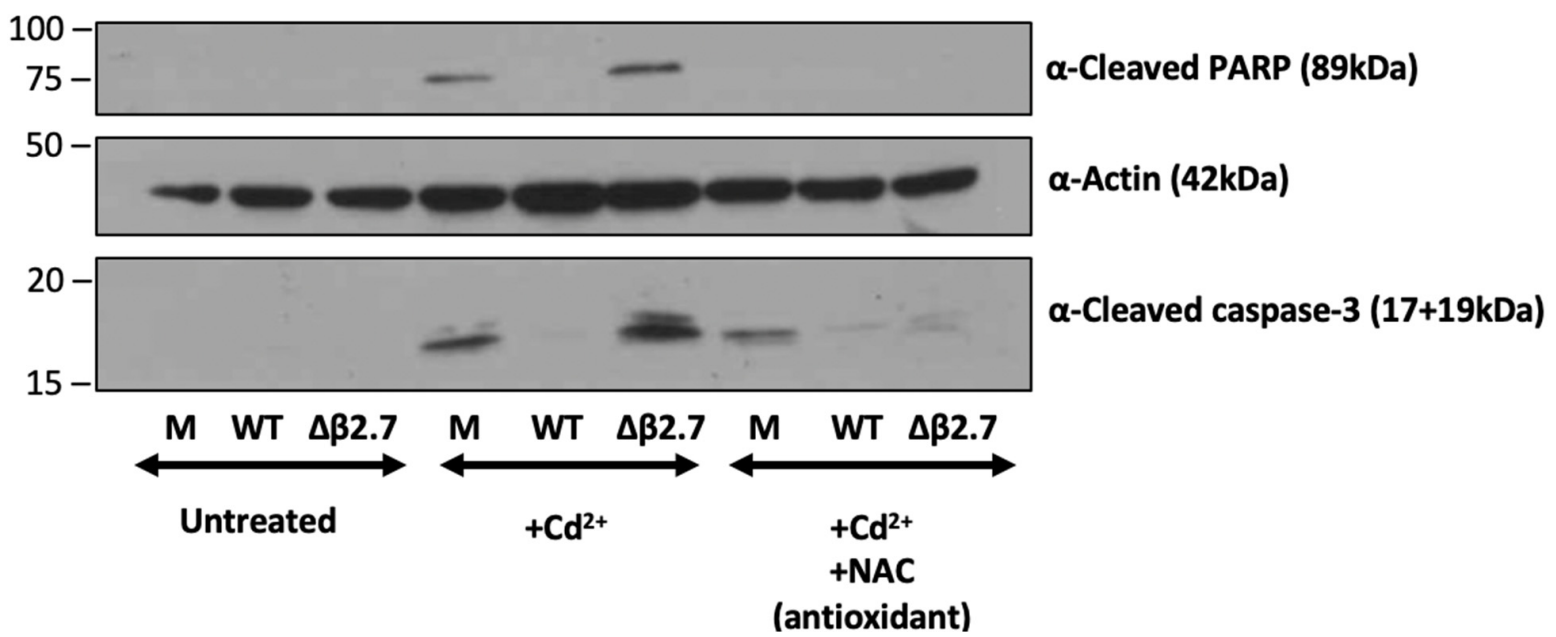

Figure 5. Lowering ROS levels with an antioxidant rescues $\Delta \beta 2.7$ virus from cadmium-induced apoptosis. (A,B) Primary CD14+ monocytes were treated with $50 \mu \mathrm{M}$ cadmium chloride and increasing concentrations of the antioxidants (A) N-acetyl cysteine (NAC) or (B) MitoTEMPO. Then, $24 \mathrm{~h}$ post treatment, cells were stained with TMRE and Hoechst and imaged by fluorescence microscopy. (C) CD14+ monocytes were mock infected or infected with WT or $\Delta \beta 2.7$ HCMV Toledo. Next, 6 d.p.i, cells were treated with $50 \mu \mathrm{M} \mathrm{CdCl}_{2}$ with or without the antioxidant NAC. Finally, $24 \mathrm{~h}$ post treatment, protein lysates were harvested and immunoblotted for cleaved caspase-3, cleaved PARP and the loading control actin. 


\subsection{WT, but Not $\Delta \beta 2.7$, Virus Infection of Monocytes Upregulates the Antioxidant Enzyme, SOD2}

Our data, so far, indicated that $\beta 2.7$ protects infected cells from the effects of high ROS levels; however, the mechanism for this was unclear. One important regulator of ROS is the mitochondrial enzyme superoxide dismutase 2 (SOD2) [44]. Electrons that leak from complex I and III of the electron transport chain due to e.g., metabolic stress, can reduce oxygen molecules to the highly reactive and damaging superoxide. SOD2 limits the accumulation of ROS by catalysing the conversion of superoxide to hydrogen peroxide, which is then further oxidized to water and oxygen by GPX-1, catalase or PDRX1 (see Figure 6A) $[45,46]$. Interestingly, SOD2 mRNA was found to be upregulated in a previous unbiased screen for altered transcripts after HCMV infection of monocytes [47].

We reasoned, therefore, that a possible mechanism of action of $\beta 2.7$ could be through modulation of SOD2 protein levels. Consequently, we analysed cellular SOD2 levels during infection in the presence or absence of $\beta 2.7$. Figure $6 \mathrm{~B}$ shows that SOD2 is significantly upregulated in monocytes infected with WT Toledo virus but not after infection with $\Delta \beta 2.7$ virus. Interestingly, a time course analysis showed that this virus-induced increase in SOD2 occurred as early as 1 d.p.i and it steadily increased over time (Figure 6C), again dependent on the presence of $\beta 2.7$.

As the cellular enzyme, GPX-1, also functions in the detoxification of ROS (see Figure 6A), we also examined levels of GPX-1 protein during infection. As shown in Figure 6D, the levels of GPX- 1 are also upregulated in WT but not $\Delta \beta 2.7$ infected monocytes, albeit not as strongly as for SOD2. Therefore, WT infection of monocytes seems to also increase levels of another antioxidant enzyme, presumably to aid in further detoxification of ROS.

Finally, we were surprised that despite only $\sim 10 \%$ of monocytic cells establishing a latent infection $[48,49]$, we observed drastic changes in cleaved caspase-3 protein levels in the total cell population (Figures 3 and 5), coupled with virus-induced protection from high ROS levels in all cells analysed (Figure 4). We reasoned that this could be explained by bystander effects, where infected monocytes might secrete factors which also result in e.g., upregulation of SOD2 in uninfected bystander cells, thereby protecting them from high ROS levels and apoptosis. To test this, we transferred supernatant from mock, WT or $\Delta \beta 2.7$ infected monocytes to uninfected, naïve monocytes, and 3 days post treatment, levels of SOD2 were assessed by western blot analysis. Figure $6 \mathrm{E}$ shows that supernatants from WT infected cells, but not cells infected with $\Delta \beta 2.7$ virus, strongly upregulated SOD2 in naïve CD14+ monocytes, indicating the involvement of secreted factor(s) in $\beta 2.7$-dependent SOD2 upregulation. To rule out that this effect was a result of residual infectious virus in the infected cell supernatants, we UV-inactivated the supernatants prior to analysis to kill any residual progeny virus. We observed that the UV-inactivated supernatant still induced an increase in SOD2 levels (Figure 6E). 
A)

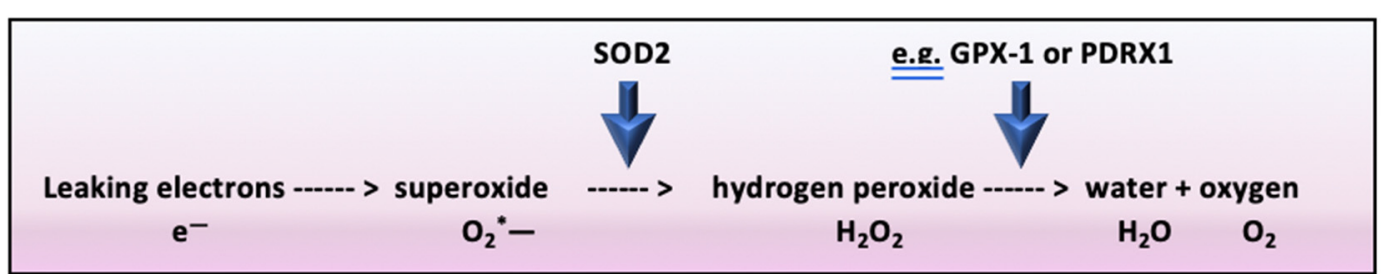

B)
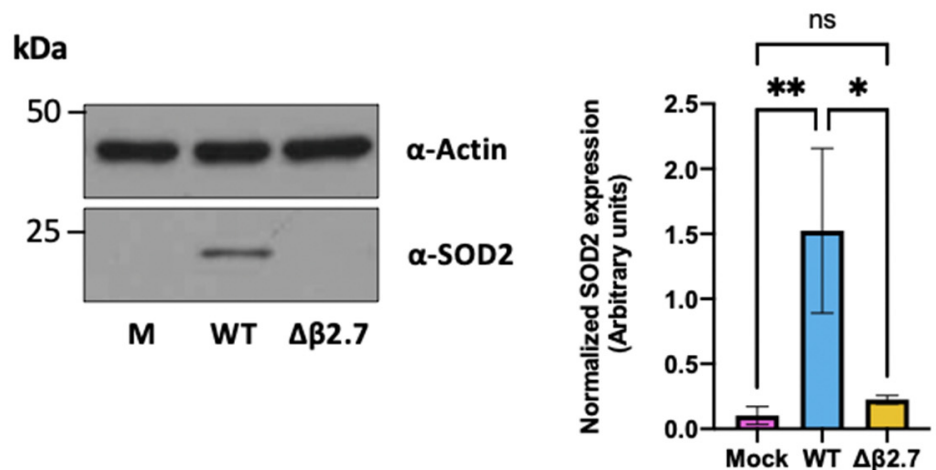

C)

$\mathrm{kDa}$

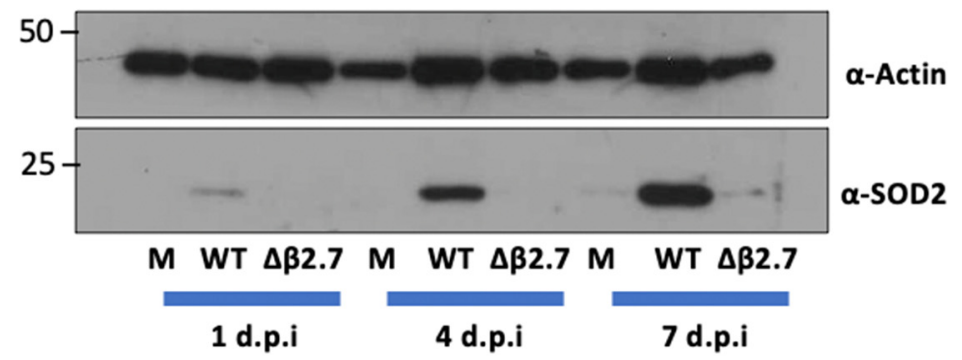

D)
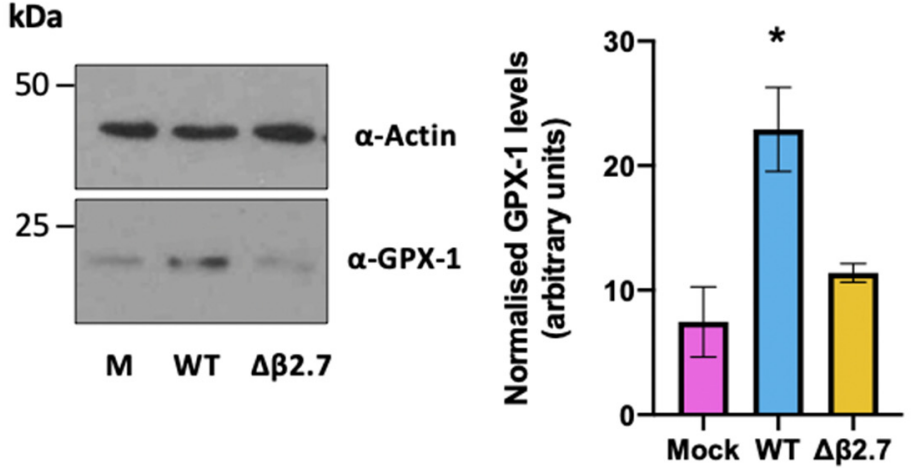

E)

kDa

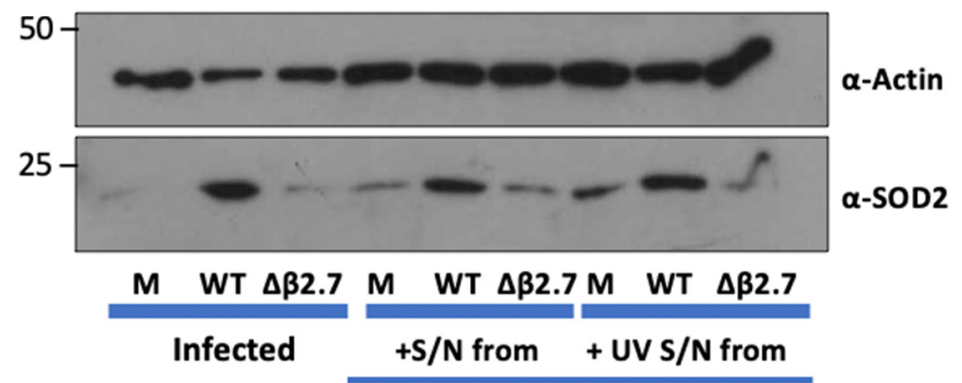

Uninfected

Figure 6. WT, but not $\Delta \beta 2.7$ infection upregulates SOD2 and GPX-1 in infected monocytes and bystander cells. (A) Electrons leaking from Complex I or III in the electron transport chain may react 
with oxygen to form superoxide. Superoxide is converted to hydrogen peroxide by the mitochondrial enzyme, SOD2, which is subsequently processed to water and oxygen by e.g., GPX-1 or PRDX1. (B) CD14+ monocytes were mock infected (M) or infected with WT or $\Delta \beta 2.7$ HCMV Toledo. 7 d.p.i, protein lysates from cells were harvested and assessed for SOD2 and actin levels by immunoblot. Graph shows densitometry from 3 independent biological repeats normalised to actin levels. Significance difference between Mock and WT and WT and $\Delta \beta 2.7$ was determined by one-way ANOVA with Tukey post hoc testing. $\mathrm{ns}=$ not significant, ${ }^{*}=p<0.05$, and ${ }^{* *}=p<0.01$. (C) Proteins from CD14+ monocytes infected with mock, WT or $\Delta \beta 2.7$ Toledo were harvested at 1, 4, and 7 d.p.i and immunoblotted for SOD2 and the loading control actin. (D) As described in (B), but protein lysates were immunoblotted for GPX-1 and actin. ${ }^{*}=p<0.05$. (E) Supernatant from CD14+ monocytes that were mock, WT or $\Delta \beta 2.7$ Toledo infected was harvested at $7 \mathrm{~d}$.p.i and either transferred directly (' $+\mathrm{S} / \mathrm{N}$ from') or first UV inactivated ('+UV S/N from') and then placed onto uninfected CD14+ monocytes. Then, 3 days after treatment with supernatants, protein was harvested and immunoblotted for SOD2 and actin.

\section{Discussion}

$\beta 2.7$ is an HCMV-encoded long non-coding RNA that is the most abundant latent viral transcript. Despite this, its role during latency remains has remained undefined and no latency-associated function for it has ever been described. We now show that $\beta 2.7$ protects infected monocytes from apoptosis by preventing increases in ROS levels and by upregulating expression of the antioxidant enzymes, SOD2 and GPX-1.

Reactive oxygen species pose a significant problem for all cells: whilst at low levels, they have important roles in cell signalling, high levels of ROS lead to irreversible oxidation of proteins and DNA, lipid peroxidation, inhibition of MMP and ATP production, and, ultimately, apoptosis or necrosis.

In this paper, we have observed that HCMV protects against ROS during infection of monocytes and prevents apoptosis of the infected host cell, likely optimising maintenance of the latent reservoir to enable efficient reactivation and dissemination of reactivated virus.

We recognise that in our analyses, we generated ROS artificially with cadmium chloride in order to address the ability of HCMV to combat ROS induction. However, infected monocytes are likely to face many natural ROS-inducing insults during latent carriage in vivo. Firstly, monocytes are drawn to sites of inflammation, in which ROS levels are high [50]. Proinflammatory cytokines such as TNF $\alpha$ and IL-1 $\beta$, likely to be abundant in such environments, elicit mitochondrial ROS formation [51]. Mitochondrial ROS in turn can drive higher TNF $\alpha$ expression [52], resulting in a positive feedback loop for ROS production [53]. Secondly, high ROS levels are involved in the differentiation of monocytes to macrophages or dendritic cells [54-57], and can also increase after periods of hypoxia when blood flow is restored (ischaemia/reperfusion injury) (reviewed in [58,59]).

Furthermore, we hypothesize that latent infection itself raises ROS levels in the cell, given that we saw higher ROS levels in $\Delta \beta 2.7$ infected monocytes compared to mock infected, even in the absence of cadmium ion treatment. Indeed, binding of HCMV virions to cells has been shown to generate ROS [60], and it is also possible that latent HCMV alters mitochondrial metabolism as it does in lytic infection [61,62], resulting in higher ROS generation that needs to be corrected for.

In this study, we found that as well as protecting infected monocytes from high ROS levels, $\beta 2.7$ also prevents high ROS levels and upregulates SOD2 in uninfected bystander cells by means of a secreted factor. Preventing ROS-induced cell death in surrounding cells may indirectly protect the infected cell; death of myeloid cells is thought to mediate further local inflammation and associated tissue damage [54]. Furthermore, although this paper has focussed on ROS-induced apoptosis, mitochondrial ROS are also important intracellular signalling molecules, and can activate JNK and p38 MAPK, resulting in proinflammatory cytokine IL-6 and TNF $\alpha$ secretion in monocytes [52]. Additionally, 
mitochondrial ROS activate the inflammasome in monocytes via redox sensitive TBP-2, resulting in the secretion of IL-1 $\beta$ and IL-18 [50,63-65]. Therefore, dampening ROS in surrounding cells may also prevent local production of proinflammatory cytokines. As well as protecting cells from inflammatory damage, this could also contribute to immune evasion by the infected monocyte. It would be interesting to test whether the supernatant from infected monocytes can additionally upregulate SOD2 in other types of cells which could be uninfected bystanders in vivo.

We are, as yet, uncertain of the identity of the secreted factor responsible for SOD2 upregulation. SOD2 is often upregulated by proinflammatory cytokines [66], however, this seems incompatible with latent infection which overall simulates an anti-inflammatory microenvironment $[67,68]$. At this time, it also remains unclear how $\beta 2.7$ may stimulate production of the secreted activator of SOD2, although it is well established that lncRNAs can modulate gene expression in a number of ways: they can bind promoters and recruit transcription factors, they can bind to multiple miRNAs and prevent them from degrading their target or can bind and sequester proteins away from their targets (reviewed in [69,70]).

Our analysis has focussed on mitochondrial ROS: the ROS dye used herein (MitoSOX) localises to the mitochondria, as does one of the antioxidants we used to protect against cadmium toxicity (MitoTEMPO). However, other sources of ROS exist within monocytes. For example, inflammation can drive neutrophils and monocytes to produce extracellular ROS via NADPH oxidase 2 (NOX2), which can diffuse back into cells [53]. Monocytes are thought to be particularly susceptible to cell death induced by this source of ROS [71]. Whilst SOD2 is localised in the mitochondria and limited to dealing with mitochondrial superoxide, we also found that HCMV significantly upregulated another antioxidant enzyme, GPX-1, which is mostly cytoplasmic, and, therefore, could mitigate these other sources of ROS [72].

Finally, whilst it is known that expression of $\beta 2.7$ in isolation can protect cells from rotenone-induced apoptosis during permissive infection [14], it is not known if this is also the case in undifferentiated myeloid cells. At present, our data are consistent with $\beta 2.7$ acting directly in an antiapoptotic role. However, we accept that $\beta 2.7$ expression, or lack of expression, in myeloid cells upon infection could result in changes in expression of other viral genes involved in managing oxidative stress, mitochondrial function or apoptosis in infected myeloid cells.

In conclusion, we have shown that the HCMV long non-coding RNA, $\beta 2.7$, which is the most abundant latent viral transcript but previously had no defined role during latency, protects against ROS-induced apoptosis and upregulates antioxidant enzymes in infected and bystander monocytes. This function of $\beta 2.7$ likely plays a key role in the maintenance and dissemination of latent HCMV infection in the host.

Author Contributions: Conceptualization, M.R.P. and J.H.S.; methodology, M.R.P. and J.H.S.; formal analysis, M.R.P. and J.H.S.; investigation, M.R.P. and J.H.S.; resources, K.L.R., E.A.M. and J.H.S.; data curation, M.R.P. and J.H.S.; writing-original draft preparation, M.R.P. and J.H.S.; writing-review and editing, M.R.P., E.A.M. and J.H.S.; visualization, J.H.S.; supervision, J.H.S.; project administration, J.H.S.; funding acquisition, J.H.S. All authors have read and agreed to the published version of the manuscript.

Funding: This research was funded by a Medical Research Council (MRC) Programme Grant (grant number MR/S00081X/1) and an MRC Doctoral Training grant (grant number RG86932).

Institutional Review Board Statement: The study was conducted according to the guidelines of the Declaration of Helsinki, and approved by the Institutional Review Board (or Ethics Committee) of Health Research Authority (HRA) Cambridge Central Research Ethics Committee (REC reference 97/092).

Informed Consent Statement: Informed consent was obtained from all subjects involved in the study. 
Acknowledgments: We thank Paula Rayner and Roy Whiston for technical assistance.

Conflicts of Interest: The authors declare no conflict of interest.

\section{References}

1. Cannon, M.J.; Schmid, D.S.; Hyde, T.B. Review of Cytomegalovirus Seroprevalence and Demographic Characteristics Associated with Infection. Rev. Med. Virol. 2010, 20, 202-213. [CrossRef] [PubMed]

2. Hahn, G.; Jores, R.; Mocarski, E.S. Cytomegalovirus Remains Latent in a Common Precursor of Dendritic and Myeloid Cells. Proc. Natl. Acad. Sci. USA 1998, 95, 3937-3942. [CrossRef] [PubMed]

3. Mendelson, M.; Monard, S.; Sissons, P.; Sinclair, J. Detection of Endogenous Human Cytomegalovirus in CD34+ Bone Marrow Progenitors. J. Gen. Virol. 1996, 77 Pt 12, 3099-3102. [CrossRef] [PubMed]

4. Söderberg-Nauclér, C.; Fish, K.N.; Nelson, J.A. Reactivation of Latent Human Cytomegalovirus by Allogeneic Stimulation of Blood Cells from Healthy Donors. Cell 1997, 91, 119-126. [CrossRef]

5. Taylor-Wiedeman, J.; Sissons, J.G.; Borysiewicz, L.K.; Sinclair, J.H. Monocytes Are a Major Site of Persistence of Human Cytomegalovirus in Peripheral Blood Mononuclear Cells. J. Gen. Virol. 1991, 72 Pt 9, 2059-2064. [CrossRef]

6. von Laer, D.; Meyer-Koenig, U.; Serr, A.; Finke, J.; Kanz, L.; Fauser, A.A.; Neumann-Haefelin, D.; Brugger, W.; Hufert, F.T. Detection of Cytomegalovirus DNA in CD34+ Cells from Blood and Bone Marrow. Blood 1995, 86, 4086-4090. [CrossRef]

7. Collins-McMillen, D.; Chesnokova, L.; Lee, B.-J.; Fulkerson, H.L.; Brooks, R.; Mosher, B.S.; Yurochko, A.D. HCMV Infection and Apoptosis: How Do Monocytes Survive HCMV Infection? Viruses 2018, 10, 533. [CrossRef]

8. Elder, E.; Sinclair, J. HCMV Latency: What Regulates the Regulators? Med. Microbiol. Immunol. 2019, 208, 431-438. [CrossRef]

9. Cheng, S.; Caviness, K.; Buehler, J.; Smithey, M.; Nikolich-Žugich, J.; Goodrum, F. Transcriptome-Wide Characterization of Human Cytomegalovirus in Natural Infection and Experimental Latency. Proc. Natl. Acad. Sci. USA 2017, 114, E10586-E10595. [CrossRef]

10. Shnayder, M.; Nachshon, A.; Krishna, B.; Poole, E.; Boshkov, A.; Binyamin, A.; Maza, I.; Sinclair, J.; Schwartz, M.; Stern-Ginossar, N. Defining the Transcriptional Landscape during Cytomegalovirus Latency with Single-Cell RNA Sequencing. mBio 2018, 9 , e00013-18. [CrossRef]

11. Rossetto, C.C.; Tarrant-Elorza, M.; Pari, G.S. Cis and Trans Acting Factors Involved in Human Cytomegalovirus Experimental and Natural Latent Infection of CD14 (+) Monocytes and CD34 (+) Cells. PLoS Pathog. 2013, 9, e1003366. [CrossRef] [PubMed]

12. Zhang, X.; Wang, W.; Zhu, W.; Dong, J.; Cheng, Y.; Yin, Z.; Shen, F. Mechanisms and Functions of Long Non-Coding RNAs at Multiple Regulatory Levels. Int. J. Mol. Sci. 2019, 20, 5573. [CrossRef] [PubMed]

13. Gatherer, D.; Seirafian, S.; Cunningham, C.; Holton, M.; Dargan, D.J.; Baluchova, K.; Hector, R.D.; Galbraith, J.; Herzyk, P.; Wilkinson, G.W.G.; et al. High-Resolution Human Cytomegalovirus Transcriptome. Proc. Natl. Acad. Sci. USA 2011, 108, 19755-19760. [CrossRef]

14. Reeves, M.B.; Davies, A.A.; McSharry, B.P.; Wilkinson, G.W.; Sinclair, J.H. Complex I Binding by a Virally Encoded RNA Regulates Mitochondria-Induced Cell Death. Science 2007, 316, 1345-1348. [CrossRef]

15. Poole, E.; Reeves, M.; Sinclair, J.H. The Use of Primary Human Cells (Fibroblasts, Monocytes, and Others) to Assess Human Cytomegalovirus Function. In Methods in Molecular Biology (Clifton, N.J.); Humana Press: Totowa, NJ, USA, 2014; Volume 1119, pp. 81-98.

16. McSharry, B.P.; Tomasec, P.; Neale, M.L.; Wilkinson, G.W.G. The Most Abundantly Transcribed Human Cytomegalovirus Gene (Beta 2.7) Is Non-Essential for Growth in Vitro. J. Gen. Virol. 2003, 84, 2511-2516. [CrossRef] [PubMed]

17. O'Connor, C.M.; Murphy, E.A. A Myeloid Progenitor Cell Line Capable of Supporting Human Cytomegalovirus Latency and Reactivation, Resulting in Infectious Progeny. J. Virol. 2012, 86, 9854-9865. [CrossRef] [PubMed]

18. Murphy, E.; Vaníček, J.; Robins, H.; Shenk, T.; Levine, A.J. Suppression of Immediate-Early Viral Gene Expression by HerpesvirusCoded MicroRNAs: Implications for Latency. Proc. Natl. Acad. Sci. USA 2008, 105, 5453-5458. [CrossRef]

19. Warming, S.; Costantino, N.; Court, D.L.; Jenkins, N.A.; Copeland, N.G. Simple and Highly Efficient BAC Recombineering Using GalK Selection. Nucleic Acids Res. 2005, 33, e36. [CrossRef]

20. Lau, B.; Poole, E.; Van Damme, E.; Bunkens, L.; Sowash, M.; King, H.; Murphy, E.; Wills, M.; Van Loock, M.; Sinclair, J. Human Cytomegalovirus MiR-UL112-1 Promotes the down-Regulation of Viral Immediate Early-Gene Expression during Latency to Prevent T-Cell Recognition of Latently Infected Cells. J. Gen. Virol. 2016, 97, 2387-2398. [CrossRef]

21. Elder, E.G.; Krishna, B.A.; Poole, E.; Perera, M.; Sinclair, J. Regulation of Host and Viral Promoters during Human Cytomegalovirus Latency via US28 and CTCF. J. Gen. Virol. 2021, 102, 001609. [CrossRef]

22. Alkharashi, N.A.O.; Periasamy, V.S.; Athinarayanan, J.; Alshatwi, A.A. Cadmium Triggers Mitochondrial Oxidative Stress in Human Peripheral Blood Lymphocytes and Monocytes: Analysis Using in Vitro and System Toxicology Approaches. J. Trace Elem. Med. Biol. Organ. Soc. Miner. Trace Elem. GMS 2017, 42, 117-128. [CrossRef] [PubMed]

23. Fuente, H.D.L.; Portales-Perez, D.; Baranda, L.; Diaz-Barriga, F.; Saavedra-Alanis, V.; Layseca, E.; González-Amaro, R. Effect of Arsenic, Cadmium and Lead on the Induction of Apoptosis of Normal Human Mononuclear Cells. Clin. Exp. Immunol. 2002, 129, 69-77. [CrossRef] [PubMed] 
24. Li, M.; Kondo, T.; Zhao, Q.-L.; Li, F.-J.; Tanabe, K.; Arai, Y.; Zhou, Z.-C.; Kasuya, M. Apoptosis Induced by Cadmium in Human Lymphoma U937 Cells through Ca2+-Calpain and Caspase-Mitochondria- Dependent Pathways *. J. Biol. Chem. 2000, 275, 39702-39709. [CrossRef] [PubMed]

25. Olszowski, T.; Baranowska-Bosiacka, I.; Gutowska, I.; Piotrowska, K.; Mierzejewska, K.; Korbecki, J.; Kurzawski, M.; Tarnowski, M.; Chlubek, D. The Effects of Cadmium at Low Environmental Concentrations on THP-1 Macrophage Apoptosis. Int. J. Mol. Sci. 2015, 16, 21410-21427. [CrossRef]

26. Hossein-Khannazer, N.; Azizi, G.; Eslami, S.; Mohammed, H.A.; Fayyaz, F.; Hosseinzadeh, R.; Usman, A.B.; Kamali, A.N.; Mohammadi, H.; Jadidi-Niaragh, F.; et al. The Effects of Cadmium Exposure in the Induction of Inflammation. Immunopharmacol. Immunotoxicol. 2020, 42, 1-8. [CrossRef]

27. Perry, S.W.; Norman, J.P.; Barbieri, J.; Brown, E.B.; Gelbard, H.A. Mitochondrial Membrane Potential Probes and the Proton Gradient: A Practical Usage Guide. BioTechniques 2011, 50, 98-115. [CrossRef]

28. Elder, E.; Krishna, B.; Williamson, J.; Aslam, Y.; Farahi, N.; Wood, A.; Romashova, V.; Roche, K.; Murphy, E.; Chilvers, E.; et al. Monocytes Latently Infected with Human Cytomegalovirus Evade Neutrophil Killing. iScience 2019, 12, 13-26. [CrossRef]

29. Sinclair, J.; Sissons, P. Latency and Reactivation of Human Cytomegalovirus. J. Gen. Virol. 2006, 87, 1763-1779. [CrossRef]

30. Kew, V.G.; Wills, M.R.; Reeves, M.B. LPS Promotes a Monocyte Phenotype Permissive for Human Cytomegalovirus ImmediateEarly Gene Expression upon Infection but Not Reactivation from Latency. Sci. Rep. 2017, 7, 810. [CrossRef]

31. Hargett, D.; Shenk, T.E. Experimental Human Cytomegalovirus Latency in CD14+ Monocytes. Proc. Natl. Acad. Sci. USA 2010, 107, 20039-20044. [CrossRef]

32. Goodrum, F.D.; Jordan, C.T.; High, K.; Shenk, T. Human Cytomegalovirus Gene Expression during Infection of Primary Hematopoietic Progenitor Cells: A Model for Latency. Proc. Natl. Acad. Sci. USA 2002, 99, 16255-16260. [CrossRef] [PubMed]

33. Stern, J.L.; Slobedman, B. Human Cytomegalovirus Latent Infection of Myeloid Cells Directs Monocyte Migration by UpRegulating Monocyte Chemotactic Protein-1. J. Immunol. 2008, 180, 6577-6585. [CrossRef] [PubMed]

34. Goodrum, F.; Reeves, M.; Sinclair, J.; High, K.; Shenk, T. Human Cytomegalovirus Sequences Expressed in Latently Infected Individuals Promote a Latent Infection in Vitro. Blood 2007, 110, 937-945. [CrossRef] [PubMed]

35. Fu, M.; Gao, Y.; Zhou, Q.; Zhang, Q.; Peng, Y.; Tian, K.; Wang, J.; Zheng, X. Human Cytomegalovirus Latent Infection Alters the Expression of Cellular and Viral MicroRNA. Gene 2014, 536, 272-278. [CrossRef] [PubMed]

36. Zhang, Q.; Song, X.; Ma, P.; Lv, L.; Zhang, Y.; Deng, J.; Zhang, Y. Human Cytomegalovirus MiR-US33as-5p Targets IFNAR1 to Achieve Immune Evasion During Both Lytic and Latent Infection. Front. Immunol. 2021, 12, 461. [CrossRef]

37. Jenkins, C.; Abendroth, A.; Slobedman, B. A Novel Viral Transcript with Homology to Human Interleukin-10 Is Expressed during Latent Human Cytomegalovirus Infection. J. Virol. 2004, 78, 1440-1447. [CrossRef]

38. Ly, J.D.; Grubb, D.R.; Lawen, A. The Mitochondrial Membrane Potential $(\Delta \psi \mathrm{m})$ in Apoptosis; an Update. Apoptosis 2003, 8 , 115-128. [CrossRef]

39. Zhao, J.; Sinclair, J.; Houghton, J.; Bolton, E.; Bradley, A.; Lever, A. Cytomegalovirus B2.7 RNA Transcript Protects Endothelial Cells against Apoptosis during Ischemia/Reperfusion Injury. J. Heart Lung Transplant. 2010, 29, 342-345. [CrossRef]

40. Halliwell, B.; Gutteridge, J.M.C. Free Radicals in Biology and Medicine; Oxford University Press: Oxford, UK, 2015; ISBN 978-0-19871748-5.

41. Murphy, M.P. How Mitochondria Produce Reactive Oxygen Species. Biochem. J. 2009, 417, 1-13. [CrossRef]

42. Schieber, M.; Chandel, N.S. ROS Function in Redox Signaling and Oxidative Stress. Curr. Biol. 2014, 24, R453-R462. [CrossRef]

43. Dupré-Crochet, S.; Erard, M.; Nüße, O. ROS Production in Phagocytes: Why, When, and Where? J. Leukoc. Biol. 2013, 94, 657-670. [CrossRef] [PubMed]

44. Wang, Y.; Branicky, R.; Noë, A.; Hekimi, S. Superoxide Dismutases: Dual Roles in Controlling ROS Damage and Regulating ROS Signaling. J. Cell Biol. 2018, 217, 1915-1928. [CrossRef] [PubMed]

45. Zhao, R.-Z.; Jiang, S.; Zhang, L.; Yu, Z.-B. Mitochondrial Electron Transport Chain, ROS Generation and Uncoupling (Review). Int. J. Mol. Med. 2019, 44, 3-15. [CrossRef] [PubMed]

46. Kim, Y.S.; Gupta Vallur, P.; Phaëton, R.; Mythreye, K.; Hempel, N. Insights into the Dichotomous Regulation of SOD2 in Cancer. Antioxid. Basel Switz. 2017, 6, 86. [CrossRef]

47. Chan, G.; Nogalski, M.T.; Bentz, G.L.; Smith, M.S.; Parmater, A.; Yurochko, A.D. PI3K-Dependent Upregulation of Mcl-1 by Human Cytomegalovirus Is Mediated by Epidermal Growth Factor Receptor and Inhibits Apoptosis in Short-Lived Monocytes. J. Immunol. 2010, 184, 3213-3222. [CrossRef]

48. Krishna, B.A.; Spiess, K.; Poole, E.L.; Lau, B.; Voigt, S.; Kledal, T.N.; Rosenkilde, M.M.; Sinclair, J.H. Targeting the Latent Cytomegalovirus Reservoir with an Antiviral Fusion Toxin Protein. Nat. Commun. 2017, 8, 14321. [CrossRef]

49. Poole, E.; Lau, J.C.H.; Sinclair, J. Latent Infection of Myeloid Progenitors by Human Cytomegalovirus Protects Cells from FAS-Mediated Apoptosis through the Cellular IL-10/PEA-15 Pathway. J. Gen. Virol. 2015, 96, 2355-2359. [CrossRef]

50. Mittal, M.; Siddiqui, M.R.; Tran, K.; Reddy, S.P.; Malik, A.B. Reactive Oxygen Species in Inflammation and Tissue Injury. Antioxid. Redox Signal. 2014, 20, 1126-1167. [CrossRef]

51. Yang, D.; Elner, S.G.; Bian, Z.-M.; Till, G.O.; Petty, H.R.; Elner, V.M. Pro-Inflammatory Cytokines Increase Reactive Oxygen Species through Mitochondria and NADPH Oxidase in Cultured RPE Cells. Exp. Eye Res. 2007, 85, 462-472. [CrossRef] 
52. Bulua, A.C.; Simon, A.; Maddipati, R.; Pelletier, M.; Park, H.; Kim, K.-Y.; Sack, M.N.; Kastner, D.L.; Siegel, R.M. Mitochondrial Reactive Oxygen Species Promote Production of Proinflammatory Cytokines and Are Elevated in TNFR1-Associated Periodic Syndrome (TRAPS). J. Exp. Med. 2011, 208, 519-533. [CrossRef]

53. Blaser, H.; Dostert, C.; Mak, T.W.; Brenner, D. TNF and ROS Crosstalk in Inflammation. Trends Cell Biol. 2016, 26, 249-261. [CrossRef] [PubMed]

54. Tan, H.-Y.; Wang, N.; Li, S.; Hong, M.; Wang, X.; Feng, Y. The Reactive Oxygen Species in Macrophage Polarization: Reflecting Its Dual Role in Progression and Treatment of Human Diseases. Oxid. Med. Cell. Longev. 2016, 2016, e2795090. [CrossRef] [PubMed]

55. Zhang, Y.; Choksi, S.; Chen, K.; Pobezinskaya, Y.; Linnoila, I.; Liu, Z.-G. ROS Play a Critical Role in the Differentiation of Alternatively Activated Macrophages and the Occurrence of Tumor-Associated Macrophages. Cell Res. 2013, 23, 898-914. [CrossRef] [PubMed]

56. Xu, Q.; Choksi, S.; Qu, J.; Jang, J.; Choe, M.; Banfi, B.; Engelhardt, J.F.; Liu, Z. NADPH Oxidases Are Essential for Macrophage Differentiation *. J. Biol. Chem. 2016, 291, 20030-20041. [CrossRef] [PubMed]

57. Del Prete, A.; Zaccagnino, P.; Di Paola, M.; Saltarella, M.; Oliveros Celis, C.; Nico, B.; Santoro, G.; Lorusso, M. Role of Mitochondria and Reactive Oxygen Species in Dendritic Cell Differentiation and Functions. Free Radic. Biol. Med. 2008, 44, 1443-1451. [CrossRef]

58. Robins, M.; Wyatt, H.A. Hyperbaric Treatment of Ischemia Reperfusion Injury. In StatPearls; StatPearls Publishing: Treasure Island, FL, USA, 2021.

59. Granger, D.N.; Kvietys, P.R. Reperfusion Injury and Reactive Oxygen Species: The Evolution of a Concept. Redox Biol. 2015, 6, 524-551. [CrossRef]

60. Speir, E.; Shibutani, T.; Yu, Z.X.; Ferrans, V.; Epstein, S.E. Role of Reactive Oxygen Intermediates in Cytomegalovirus Gene Expression and in the Response of Human Smooth Muscle Cells to Viral Infection. Circ. Res. 1996, 79, 1143-1152. [CrossRef]

61. Combs, J.A.; Norton, E.B.; Saifudeen, Z.R.; Bentrup, K.H.Z.; Katakam, P.V.; Morris, C.A.; Myers, L.; Kaur, A.; Sullivan, D.E.; Zwezdaryk, K.J. Human Cytomegalovirus Alters Host Cell Mitochondrial Function during Acute Infection. J. Virol. 2020, 94, e01183-19. [CrossRef]

62. Karniely, S.; Weekes, M.P.; Antrobus, R.; Rorbach, J.; van Haute, L.; Umrania, Y.; Smith, D.L.; Stanton, R.J.; Minczuk, M.; Lehner, P.J.; et al. Human Cytomegalovirus Infection Upregulates the Mitochondrial Transcription and Translation Machineries. $m B i o$ 2016, 7, e00029-16. [CrossRef]

63. Zhou, R.; Tardivel, A.; Thorens, B.; Choi, I.; Tschopp, J. Thioredoxin-Interacting Protein Links Oxidative Stress to Inflammasome Activation. Nat. Immunol. 2010, 11, 136-140. [CrossRef]

64. Abais, J.M.; Xia, M.; Zhang, Y.; Boini, K.M.; Li, P.-L. Redox Regulation of NLRP3 Inflammasomes: ROS as Trigger or Effector? Antioxid. Redox Signal. 2015, 22, 1111-1129. [CrossRef] [PubMed]

65. Zhou, R.; Yazdi, A.S.; Menu, P.; Tschopp, J. A Role for Mitochondria in NLRP3 Inflammasome Activation. Nature 2011, 469 , 221-225. [CrossRef] [PubMed]

66. Dosunmu-Ogunbi, A.M.; Wood, K.C.; Novelli, E.M.; Straub, A.C. Decoding the Role of SOD2 in Sickle Cell Disease. Blood Adv. 2019, 3, 2679-2687. [CrossRef] [PubMed]

67. Poole, E.; Avdic, S.; Hodkinson, J.; Jackson, S.; Wills, M.; Slobedman, B.; Sinclair, J. Latency-Associated Viral Interleukin-10 (IL-10) Encoded by Human Cytomegalovirus Modulates Cellular IL-10 and CCL8 Secretion during Latent Infection through Changes in the Cellular MicroRNA Hsa-MiR-92a. J. Virol. 2014, 88, 13947-13955. [CrossRef]

68. Jackson, S.E.; Chen, K.C.; Groves, I.J.; Sedikides, G.X.; Gandhi, A.; Houldcroft, C.J.; Poole, E.L.; Montanuy, I.; Mason, G.M.; Okecha, G.; et al. Latent Cytomegalovirus-Driven Recruitment of Activated CD4+ T Cells Promotes Virus Reactivation. Front. Immunol. 2021, 12, 657945. [CrossRef]

69. Rinn, J.L.; Chang, H.Y. Genome Regulation by Long Noncoding RNAs. Annu. Rev. Biochem. 2012, 81, 145-166. [CrossRef]

70. Statello, L.; Guo, C.-J.; Chen, L.-L.; Huarte, M. Gene Regulation by Long Non-Coding RNAs and Its Biological Functions. Nat. Rev. Mol. Cell Biol. 2021, 22, 96-118. [CrossRef]

71. Ponath, V.; Kaina, B. Death of Monocytes through Oxidative Burst of Macrophages and Neutrophils: Killing in Trans. PLoS ONE 2017, 12, e0170347. [CrossRef]

72. Dahlgren, C.; Karlsson, A.; Bylund, J. Intracellular Neutrophil Oxidants: From Laboratory Curiosity to Clinical Reality. J. Immunol. 2019, 202, 3127-3134. [CrossRef] 